\title{
DERGISI
}

ANKARA UNIVERSITY

JOURNAL

SOCIAL SCIENCES

10.33537/sobild.2020.11.2.11

\section{Makale Bilgisi}

Gönderildiği tarih: Kabul edildiği tarih: Yayinlanma tarihi:

14.04.2020

26.05.2020

30.06 .2020

\section{Article Info}

Date submitted:

Date accepted:

Date published:
14.04.2020

26.05.2020

30.06.2020

\section{ADALET YÖNETIMMINNE DÖNÜŞÜM}

\author{
TRANSFORMATION IN JUSTICE ADMINISTRATION
}

\section{Havin Öner GÖREN}

Öğr.Gör.,Toros Üniversitesi Meslek Yüksekokulu, Hukuk Bölümü, havinoner@gmail.com

\section{Barış ÖVGÜN}

Doç.Dr., Ankara Üniversitesi Siyasal Bilgiler Fakültesi, Siyaset Bilimi ve Kamu Yönetimi Bölümü, bovgun@gmail.com

\section{Anahtar sözcükler}

Verimlilik; Kamu yönetimi; Adalet yönetimi; Tüketici hakem heyeti

\section{Keywords}

Productivity; Public administration; Justice administration; Consumer arbitration committee

\section{$\ddot{O z z}$}

Türkiye'de, 1980 darbesi ile başlayan, devletin yenisağ/neo-liberal dönüşümünün adalet yönetimine yansiması 2002 yılı sonrasina denk gelmektedir. Adalet yönetiminde mevcut dönüşüm, adalet hizmetlerinde verimlilik, etkinlik ve etkililik sağlama gayeleri çerçevesinde olmuştur. Çalışma, uluslararası alanda 20. yüzyılın sonunda ortaya çıkmiş olan yargıda verimlilik kavramı bağlaminda Türkiye adalet yönetiminde 2002 sonrasinda başlayan dönüşümü analiz etmektedir. Bu makale adalet yönetiminin kamu yönetimi disiplini içinde bir çalışma alanı olduğu varsayımından hareketle, adalet yönetimindeki dönüşümün yeni-sağ ile başlayan sürecin bir parçası olduğunu ileri sürmektedir. Bu politikalar teknikleştiren ve transfer eden aktörler ise uluslararast örgütlerdir. Bu çerçevede, Avrupa Birliği, Avrupa Konseyi ve Dünya Bankasi gibi uluslararası örgütlerin, adalet sisteminin dönüşümü üzerindeki etkilerini sorgulamaktadir. Sorgulama, tüketici hakem heyetlerinin yargisal verimliliğe etkisi ve önemi çerçevesinde yapilmaktadir.

\section{Abstract}

In Turkey, starting with the 1980 military coup, the State's new-right / neo-liberalism transformation of the administration of justice corresponds to reflection after 2002. The current transformation in justice administration has been frame work of efforts to provide efficiency and effectiveness in justice services. This study examines the transformation of the judiciary of Turkey started after 2002 through the concept of efficiency, which emerged at the end of the 20th century in the international area. The study suggests that the transformation in the justice administration is part of the process that starts with the new-right, assuming that justice management is a field of study within the discipline of public administration. The actors who technicalize and transfer these policies are international organizations. In this context, it questions the effects of international organizations such as the European Union, the Council of Europe and the World Bank on the transformation of the justice system. The interrogation will be carried out within the framework of the impact and importance of consumer arbitration committees on judicial efficiency. 


\section{GİRIŞ}

Gerek dünyada gerekse de Türkiye'de 1980 sonrası yaşanan dönüşümlerin en belirgin özelliği; ekonomik, sosyal ve siyasal boyutlariyla köklü düzenlemeleri beraberinde getirmesidir. Devletin yapısal ve işlevsel dönüşümünü öngören bu reformlar, her kurumun yeniden yapılandırıldığı bir dönemi işaret etmektedir. Bu dönemin en önemli özelliklerinden biri de devlete bağımsızlık bağıyla bağlı olan yargının "verimsizlik" vurgusuyla yeniden yapilandırılması sürecidir.

1980 sonrası dönemde adalet yönetimi alanının yeniden yapılandırılması sıkça tekrarlanan bir konu olmasına rağmen; yeniden yapılandırmanın işlevsel hale gelmesi özellikle 2002 sonrasinda ve de uluslararası örgütlerin reçeteleri doğrultusunda olmuştur. Bu dönemde Dünya Bankası, Avrupa Birliği ve Avrupa Konseyi gibi örgütlerin politika belgelerinde "yargıda dönüşümün" gerekliliği gündemin en önemli başliğ1 haline gelmiştir. Yargıda verimlilik konusunun işlendiği bu çalışma, özellikle hukuk, kamu yönetimi ve işletme disiplinlerinin inceleme alanında yer almaktadır. Kamu yönetimi alanında verimlilik konusunda ciddi birikimden söz edilebilirken, yargısal verimliliğe ilişkin çalışma sayısı oldukça azdır.

$\mathrm{Bu}$ çalışmada adalet yönetiminin kamu yönetimi disiplini içinde bir çalışma alanı olduğu kabul edilerek; kamu yönetimi disiplininin araçlarıla verimlilik olgusu ele alınacaktır. $\mathrm{Bu}$ çerçevede adalet yönetiminde verimlilik nasıl ele alınabilir sorusuna yanıt aranmaya çalışılacaktır. Yargısal verimliliğin arttırılması amaciyla uygulamaya konulan alternatif uyuşmazlık yollarından birisi olan Tüketici Hakem Heyetleri' nin yargısal verimliliğe etkisi ve önemi araştırılacaktır.

\section{Kamu Yönetiminde "Verimlilik" 1. Genel Olarak}

Kamu yönetiminde verimlilik nedir ve nasıl ele alınmalıdır sorusu disiplinin kuruluşundan itibaren en önemli soru ve sorunlarından birisini oluşturmaktadır. Kamu yönetimi disiplininin kuruluşunda etkili olan siyaset-yönetim ikilemi gibi bir başka ayrım H. Simon ve $D$. Waldo arasında var olan olgu-değer ayrılığıdır. Her iki ayrımın odak noktasında yer alan konu ise “verimlilik" sorunudur. Waldo' ya göre, kamu yönetimi disiplini ve verimlilik ilişkisi şu şekilde ele alınmalıdır.

Sözlükler "verimli" veya "verimlilik" için yedi veya sekiz "anlam" yazarken, verimliliğin iki temel anlamı vardır. Bu anlamlardan biri felsefi olup; enerji, güç veya sebep kavramiyla ifade edilir. Diğer anlamı mekanik veya bilimsel olarak adlandırılabilir. Özü, orantı ya da oran fikridir: harcanan enerjiyle ya da olas1 sonuçlarla karşılaştırıldığında gerçek sonuçların neler olduğunun ortaya konulmasını ifade eder. Açıkça "verimlilik", bu iki anlamda kamu yönetimi literatüründe kullanılmaktadır (Waldo, 1948: 201).
Olgu-değer ikilemi çerçevesinde Waldo' ya göre verimliliğin kendisi bir "değer" olamaz ama bir değer sisteminin aralıklarında çalışır; değer sisteminin parçaları arasındaki ilişkileri belirler; "ahlaki içeriğini" sözdizimi, emilim yoluyla ele alır. İşler basitçe "verimli" veya "verimsiz" değildir. Belirli amaçlar için verimli veya verimsizdirler. Bir amaç için verimlilik başkaları için verimsizlik anlamına gelebilir (Waldo, 1948: 202).

Waldo' nun aksine Simon ise verimliliği olgu olarak tanımlar. Verimlilik olgusu, Amerikan kamu yönetimi anlayışı temelli Wilson-Taylor-Weber üçgeninde, hukuksal yaklaşımın uzağında "teknik" temeller (Güler, 2012: 564) üzerinde yükselmiştir.

Ölçmeye dayalı bir kavram (Zengin, 2011: 43-46) olan verimlilik, Amerikan kamu yönetimi literatüründe "olgu" niteliği taşımaktadır. Verimlilik olgusu çeşitli disiplinlerin çalıșma konusunu oluștururken, kamu yönetimi alanında bu konuya sıklıkla değinilmemesi alanın siyaset-yönetim ayrımı gibi başka bir muğlak alanı oluşturmasından kaynaklanmaktadır.

Akademik disiplinler, müfredat ve fakülteler dokunulmaz bir mantıkla sabitlenemez. Gebe kalırlar, büyürler, bölünürler, yeniden birleştirilirler ve dönüştürülürler (Waldo, 1968: 478). Kamu yönetiminin yeniden yapılandırılma sürecinde, verimlilik olgusunun da kamu yönetimi disiplini açısından aynı anlamda kalmadığı, disiplinin değişimiyle birlikte dönüştüğü, günün koşullarına göre şekillendiği ve farklılaştığı varsayılmaktadır.

Kamu yönetimi disiplininde "verimlilik" klasik yaklassımdan, modern sonrası kamu yönetimi anlayışına kadar farklı anlamlarda ele alınan ve sıkça kullanilan bir olgudur. Bu olgu amaçtan çok araç niteliği tassıyarak disiplinin kuruluşundan bu yana farklı zamanlarda, farklı yaklaşımlarla gündeme gelmiştir. Kamu hizmetlerinde verimsizlik olgusu 1980 öncesi dönemde devletin yapisal ve işlevsel olarak büyümesinin kamu yönetimi alanında bürokratikleşmeyi arttırdığı söylemiyle yer bulmuştur. $\mathrm{Bu}$ durumun yapisal sorunların yanında, devletin görevlerini arttırdığı, harcamaların fazlalaştığı ve enflasyon gibi olumsuzlukları da beraberinde getirdiği söylenmiştir (Eryılmaz, 2013: 31).

1980 sonrası verimlilik olgusu "kamusal faaliyetlerin doğası gereği kaynakları verimsiz kullandığı (Aksoy, 2012: 587) iddiasıyla yeni sağ anlayışın önemli bir çıkış noktası olmuştur. Verimlilik olgusu, yeni kamu işletmeciliği anlayışıla birlikte özellikle piyasayla özdeş tutulurken, teknik bakış açısı ile somutlassmaktadır. Kamu yönetiminin "işletmeselleştirilerek" yapısal ve işlevsel dönüşümün ekonomik bir çerçeve içinde yeniden oluşturulması (Aksoy, 2012: 589) yeni sağın etkilerini kanitlar niteliktedir. Kamu yönetiminin çalıșma nesnesini ekonomik çerçevede tanımlayan bu süreçte esas olan, kamu yönetiminin "ne olması" gerektiği değil; "ne olduğu" dur. Kamu yönetiminin insanların, araçgerecin örgütlenmesi ve yönetimi olduğu tanımının temelinde devletin amaçlarının gerçekleştirilmesi olduğu söylenebilir. Burada örgüt yapıyı, yönetim 
işlevselliği anlatır (Ergun, 2012: 647-648). Devletin doğası yaptığı iş, rolü ve doldurduğu yer, kısaca işlevi tanımlandığında netleşebilir (Eroğul, 2014: 17).

\section{Türk Kamu Yönetiminde Dönüşüm}

Devlet aygıtı içerisinde kamusal mekanizmaların mümkün olduğu kadar yok edilmek istenmesi, sermaye lehine düzenlemelerin bir sonucudur (Güler, 2016: 20-21). Kamu yönetiminde dönüşüm 1980'li yıllardan sonra, önceki dönemlerden farklı olarak devletin bir bütün olarak değişime ve dönüșüme uğratıldığ1 bir görünüm sunmaktadır (Övgün, 2013: 15).

POSCDCORB (Planlama, Örgütleme, Personel, Eşgüdüm, Yönlendirme, Bütçe, Denetim) formülü çerçevesinde karşımıza çıkan yönetim süreçlerinin her aşaması reforma tabi tutulmaktadır. Planlamada, devletin üretici ve müdahaleci konumda olduğu geleneksel planlama anlayışı yerine kendini geleceğe göre şekillendiren ve ölçme boyutuyla beliren özel sektörden ithal stratejik planlama ön plana çıkmaktadır. Örgütlenme de yeni sağ politikalara ve içsel gelişmelere uygun bir şekilde yerelleşme ve merkezileşme kıskacında yeniden yapılandırılmaktadır. Personel yönetiminde ise sermaye eksenli bir bakış açısı sunan ve bu doğrultuda insanı doğrudan sermayeleştiren insan kaynakları yaklaşımı görülmektedir. Bütçe ve denetim boyutları da değişen mali sisteme uygun olarak performans temelli olarak yeniden kurgulanmakta ve analitik bütçe ile performans denetimi uygulamaları kamu yönetiminde yaygınlaştırılmaktadır. Bütün bu dönüşüm sürecinde ise verimlilik ve etkinlik kavramları kadar katılım kavramı önem kazanmakta ve yönetişim olarak kavramsallaştırılmış olan ve çok aktörlü karar verme mekanizmasında devleti pasifleştiren yeni bir model tavsiye edilmektedir (Bayramoğlu, 2005: 284-285).

Yukarıda genel hatlarıyla ele alınan dönüşüm sürecinin hayat bulmasında içsel ve dişsal olmak üzere çeşitli politika aktörleri ön plana çıkmaktadır. Kanımızca bu aktörlerden en etkililerinden biri uluslararası örgütlerdir. Yeni sağ reformlarının taşıyıcısı olan uluslararası örgütler, Türkiye'nin kamu yönetimini çeşitli anlaşmalar, teşvikler, kredi araçları ya da üyeliğe kabul ettirme gibi araçlarla yönlendirmektedirler (Övgün, 2013: 153). Özellikle 2002 sonras1 süreçte yarg1 alanında Türkiye'nin Avrupa Birliği'ne (AB) katılım sürecinde AB'nin yarg1 reformlarına verdiği uzun vadeli destek 140 milyon Avro' ya ulaşmıştır ("Yarg1 Reformlarına İlişkin ABTürkiye İşbirliği”, 2019). AB'ye üyelik sürecinde yarg1 reformunun önemi şu cümlelerde yer almaktadır. “Türkiye'nin AB'ye üyelik süreci kapsamında, yargı organlar siyasi reform sürecinin hem hedefi hem de uygulayıcisi konumundadir. Bu nedenle, yargi ve adalet sistemi Türkiye'nin AB'ye katılım sürecinin öncelikli alanları arasında yer almaktadı" (Avrupa Birliği Müzakere Sürecinde Yargı ve Temel Haklar Fasli, 2013: 58).

Uluslararası örgütler, yürütücüsü olduğu kamu yönetimi reformlarıyla katılım, şeffaflık, verimlilik, hesap verebilirlik gibi araçlarla ekonomik ve toplumsal yapının dönüşümünü piyasa odaklı olarak yeniden yapılandırmaktadırlar. Sermaye birikiminin sorunsuz işleyebilmesi adına devletin yapısal dönüşümünü öngören bu süreçte kullanılan bu araçların kamu yönetimi disiplinini nasıl dönüştürdüğü belirlenmelidir.

Kamu yönetiminde dönüşümün en önemli amaçlarından birisi olan "verimlilik", ülkenin ekonomik, siyasal, toplumsal ve tarihsel yapısı göz önüne alınarak değerlendirilmelidir. Verimlilik, kamu yönetiminin temel amacıdır ancak bu amaç sosyal ve insanca yorumlanmalidir (Waldo,1948: 197). Bir ülkenin ekonomisinde olduğu gibi kamu yönetiminde de verimlilik, öncelikli olarak toplumsal bir değer (Mıhçığlu, 2012: 408) olarak görülmeli, verimsiz olduğu düşünülen alanların tespiti ve öncelikli olarak çözüm yolları bu şekilde toplumsal uzlaşma ile çözülmelidir.

$\mathrm{Bu}$ noktada makalenin tezi yargıda dönüşümün sağlanmasında temel amaç olarak verimliliğin ön plana çıkarılmasıdır. Yapılan yapısal ve işlevsel değişiklikler bu amaçla gerçekleşmiştir.

\section{Yarg1sal Verimlilik Nedir?}

\section{Genel Olarak}

Adalet kavramı, tarihsel gelişimi içinde incelendiğinde hem kamu hizmeti hem de kamu gücü olarak değerlendirilen bir devlet isslevidir. Adaletin sağlanması için yapılan işler, doğrudan kamusal bir iş olarak nitelendirilmelidir (Kilim, 2013: 59-60). Bir kamu harcaması olan adalet hizmetinin, devlet bütçesindeki yeri ve ülke ekonomisi üzerindeki etkisi (Egeli, Yaşa, 2017: 83) önemli bir konudur. Kamusal kaynakları kullanan bu alanın verimli, etkili ve ekonomik olması gerekmektedir.

Adalet yönetimi alanı, kamu yönetimi disiplininde olduğu gibi zamanla yeni gelişmelere göre kendini değiştirmek ve yenilemek zorundadır. Yargıda verimliliğin tam olarak ne olduğu ve nasıl ölçüleceği konusunda çok az fikir birliği olmasına rağmen; yargının verimsizliğinin bir ulusun refahını ve ekonomik büyümesini (Botero, Porta, Silanes, Shleifer, Volokh, 2003: 61) doğrudan etkileyeceğini söylemek mümkündür. Mevcut etki salt ekonomik olmayı; siyasal ve sosyal alanı da kapsamaktadır. Anayasa'nın 141. maddesinde "Davalarin en az giderle ve mümkün olan süratle sonuçlandırılması, yargının görevidir denilerek "davaların makul sürede bitirilmesinin" gerekliliği ifade edilmiştir ( Anayasa Mahkemesi Kararı, 2014).

Adalet hizmetleri, hem idari ve yargisal makamları, hem de idari ve yargisal işlevleri içermektedir (Sever, 2016: 44). Kamusal faaliyetlerin verimli, etkili ve etkin olması gerekliliği söyleminin özellikle yargı bağımsızlığı söylemiyle bazı tezatlıklar içerdiği ileri sürülmektedir. Kilim, "bağımsızlığı" devletten bağımsızlık değil; devlet kurumları arasında bir denge sorunu olarak görmektedir (Kilim, 2013: 43). $\mathrm{Bu}$ fikrin ürünü devlet örgütlenmesine bağımsızlık ilişkisiyle bağlandığı varsayılan adalet yönetimi alanının kamu yönetimi disiplini aracılığıyla incelenmesine engel olduğu düşüncesidir (Kilim, 2013: 15). 
Yargının bağımsızlığı olgusu ve yargıda verimlilik olgusu zit kavramlar değildir. İyi işleyen bir yarg1 mekanizması aynı zamanda bağımsızlığın da teminatıdır. Yarg1 alanında kamu kaynaklarının kullanımında "verimlilik, kamu yönetimi disiplini alanında olduğu gibi kolaylıkla gündeme getirilememektedir. Bunun nedeni, "yarg1sal verimlilik ve yarg1 bağımsızlığı" arasında var olduğu düşünülen karşıtlık ilişkisi, tepkileri beraberinde getirebileceği düşüncesidir (Gülener, 2011: 222). Bu düşünce kuvvetler ayrılığı teorisinin siyasi bir ilke olduğu, yargılamanın niteliği gereği siyasi olmayıp; hukuki gerçeği ortaya koyma faaliyeti olduğu (Teziç, 2013: 465) gerçeğinin yansımasıdır.

Yargisal verimlilik, adalet hizmetleri üretiminde kamu kaynaklarının en iyi biçimde kullanılması ve savurganliktan uzak durulmasi anlamina gelmektedir (Doğan, Öztürk, 2018: 778-779). Bu durum, adalet yönetiminin kalitesiyle doğrudan bağlantılıdır. Adli kalite; "isabetli kararlar, düşük temyiz oranlar, zamanında verilen kararlar (makul sürede yargılama), düşük sayıda teknik hukuki hata ve adil yargılanma ilkelerinin uygulanması" sseklinde ifade edilmektedir ( Yargitay, İş Süreçlerinin Yeniden Yapılandırılması ve Verimlilik Kontrolü Projesi Bilgi Notu, 2018). Adalet hizmetinde verimlilik, adalet harcamaları sonucunda, hukuk devleti kriterlerine uygun biçimde uyuşmazlıkların çözümü ve bozulan kamu düzeninin adalet makamlarınca verilen kararlarla ne oranda yeniden kurulduğunun belirlenmesinde önemlidir (Doğan, Öztürk, 2018: 778-779).

1947 yılından itibaren Türkiye uluslararas1 örgütlerle üyelik ve adaylık süreçleri altında doğrudan bir etkileşime girmiştir. Bu örgütlerin politikalarından ve tavsiyelerinden yoğun bir şekilde etkilenmiștir. Bu etkilenme süreci özellikle 1990'l y yllarda zirve noktasına ulaşmış ve 2000'li y1llarda da büyük bir dönüşüm süreci olarak karşımıza çıkmıștır. Adalet yönetimi de doğal olarak bu dönüşüm sürecinin bir parçası olmuş ve verimlilik ve etkinlik sağlama gayeleri çerçevesinde uluslararası örgütlerin tavsiyeleri yoğun bir şekilde görülmeye başlanmış ve bu hizmet alanı hem örgütlenme hem de işleyiş açısından dönüşüme tabi tutulmuştur. Adalet yönetimi alanının uluslararası örgütlerce düzenleme konusu edilmesi 1990'lı y1lların sonlarında başlasa da esaslı dönüşüm 2004 yılında olmuştur (Kilim, 2013: 223).

Yargıda reform süreci olarak adlandırılan 2004 y1lı ve sonrası yargının verimliliğine ilişkin değerlendirmeler özellikle yargılamanın süresi ve yargının iş yükü üzerinden ilerlemektedir. Yargının iş yükünün azaltılması adına Bölge Adliye Mahkemeleri'nin kurulması ve işler haline getirilmesinin yanında alternatif uyuşmazlık yöntemlerinin önemi de bu dönemde artmıştır. Bölge Adliye Mahkemeleri aracılığıyla ilk derece mahkemelerince verilen kararların bir kısmının doğrudan Yargitay ve Danıştay'a gitmeden çözüme kavuşturulması amaçlanmaktadır. Böylece Yargitay ve Danıştay'ın iş yükünün azalması, davaların daha hızlı biçimde kesin karara bağlanması amaçlanmaktadır. Bölge adliye mahkemelerinin temel kuruluş gerekçesi yargının iş yükünü azaltmaktır.
Yargıda iş yükünün azaltılması adına sunulan önerilerin mevcut sistemin var olan sorunlarını azaltmadığı görülmüştür. Hakim ve savc1 sayısının arttırılması önerisi ve yüksek yargıda daire sayısının arttırılması gerekliliği ilerleyen zamanlarda iş yükünün azalmasıyla sonuçlanmamıştır (Adli İstatistik, 2018: 5). 2010 yılında hakim ve savciların sayısı toplamda 7.800 iken, bu say1 2017'de 11.530 olmuştur (Adli İstatistikler, 2017: 1).

Çalışmada yargısal verimlilik, yapısal dönüşüm açısından bürokrasiye etkileri, işlevsel açıdan verimliliğin nasıl ölçülebileceği ve sonuç olarak dönüşümün kamuoyu açısından nasıl algılandığı noktasında ele alınacaktır.

\section{Yargısal Verimliliğin Kapsamı}

\section{A. Bürokrasinin Tasfiyesi}

Bürokrasi, kapitalist toplumlarda ortaya çıkan bir örgütlenme biçimi ve modern yönetim tipidir (Güler, 2013: 15). Bürokrasi, literatürün önemli bir kısmında "örgüt tipi” olarak kullanılmaktadır. Bu bakış açısıyla bürokrasi evrensel bir olgu olarak ele alınmakta ve her ülkede, benzer araçlar ve amaçlarla dönüştürülmeye çalış1lmaktadır. Uzmanlaşmaya dayalı işbölümü üzerinde yükselen, otorite ve hiyerarşinin var olduğu yönetim yapısını (Özer, 2013: 44) ifade eden bürokrasinin, örgüt tipi anlamı yanında, patolojik olarak kırtasiyecilik ve devleti işaret eden yönetim biçimi gibi anlamları da vardır.

Bürokrasi kavramı bu çalışmada yönetim biçimi olarak ele alınacaktır (Güler, 2011: 80-81). Bu nedenle modern (ulus) devletin yönetim biçimi olan bürokrasinin değişimi ekonomik ve toplumsal yapıda devletin işlevlerinin değişmesi anlamına gelmektedir. Dolayısıyla kapitalizmle doğrudan bağlantılı olan modern devlet ve bu devletin yönetim biçimi olan bürokrasi kapitalist sistemden ayrı düşünülemez. Weber bürokrasi olmaksızın kapitalist üretimin devam edemeyeceğini belirtir. Farklı tarihsel kaynaklardan doğmuş olmalarına rağmen; kapitalizm ve bürokratik düzen, modern gelişme aşamalarında bürokratik mekanizmayı besleme eğiliminde olmuşlardır (Weber, 2005: 52).

Bat1 Avrupa demokrasilerinin şiddetli mali krizinin bir sonucu olarak, piyasa odaklı idari reformlar, kamu bürokrasilerinin geleneksel özelliklerinin çoğunu yeniden şekillendirmiştir (Peters, Pierre,1998: 235). Yargidaki bürokratik yapilanma işlerin gecikmesi, kırtasiyecilik gibi söylemlerle daha çok zaman harcama noktasında eleştirilmektedir (Eryılmaz, 2013: 263). Bürokrasinin bu süreçte üzerinde durulan en önemli özelliği, şüphesiz "verimsizliği" söylemi olmuştur. Bürokrasinin tasfiye edilmesi iddiası ise bürokratik oligarşi anlayışına paralel olarak bürokratik yönetimin sonuna gelindiği yönündedir. Robert Michels oligarşi tehdidinin her örgüt yapısında var olabileceğini ancak bunun ne zaman gerçekleşeceğine ilişkin olarak "er ya da geç olacak" şeklinde ifade kullanmıştır. Robert Michels tarafından ortaya atılan "oligarşinin demir yasası" bu anlamda "oligarşinin demir tehdidi" olarak ele alınabilir (Diefenbach, 2018: 14). 
İlk bürokrasi kuramcısı ve bürokrasi kuramını verimlilik üzerine temellendiren Weber'e göre bürokrasinin önemi şu sözlerle ifade edilmiştir:

"Halkın bürokrasinin kötülüklerinden yakınması ve bir an bile sürekli idari işin, dairede/büroda çalişan resmi memurlar dışında herhangi bir yoldan yerine getirilebileceğinin sanılması bir illüzyondan ibarettir. Bütün günlük hayat düzeni bu çerçeveye uyulması yoluyla biçimlendirilmektedir. Çünkü diğer şeyler aynı kaldığında, biçimsel ve teknik açıdan bürokratik yönetim en rasyonel yönetim șeklidir. Yönetim alanında bir tercih yap1lacaksa bu bürokrasi ile amatörlük arasında yapılabilir" (Weber, 2005: 51).

Weber'in bürokrasi anlayışının üstünlüklerinin yanında belli başlı sorunlara kaynaklık ettiği düşüncesi adalet yönetimi için de söz konusudur. Özellikle 1980 sonrasında kamu işletmeciliği/yeni kamu işletmeciliği anlayışıyla başlayan bu süreçte kamu hizmetlerinin daha az kaynak kullanarak daha çok çıktı üretebilmesi hedefi bürokratik yapılanmanın bu yönde eleştirilmesine neden olmuştur.

Bu eleştirileri üç başlıkta toplamak mümkündür. Bunlardan ilki, dava yolunun gerekli olmadığ 1 ve bürokratik işleyişte çözülebilecek bir takım sorunların dava konusu yapılmasıdır. Bu duruma örnek olarak; Tüketici Hakem Heyetleri'ne rağmen Tüketici Mahkemeleri'nde yıl içinde açılan dava sayısının 2011'de 24.518 iken, 2018'de 56.991 olmas 1 gösterilebilir (Adli İstatistik,2018). İkinci temel sorun ise, dava yolunun ve iş süreçlerinin kırtasiyecilik nedeniyle karmaşıklaşmasıdır. Tüketici Mahkemeleri'nde bir davanın ortalama görülme süresi 2011'de 283 gün iken bu say1 2018'de 437 gün olmuştur (Adli İstatistik,2018). Üçüncü ve son eleştiri ise hakimlerin takdir yetkisinin kısıtlanmasıdır (Sarı, 2016: 251-257). Uygulanan kuralların ayrıntilı ve detaylı olması takdir yetkisi açısından dikkat çekicidir.

$\mathrm{Bu}$ üç sorun içerisinde bürokrasinin tasfiyesi özellikle ikinci sebepten dolayı gündemin en önemli konusu olmuştur. Yargısal verimlilik, yargısal hizmetlerde bürokrasinin olumsuz anlamı olarak "kırtasiyecilik" üzerinden ele alınarak, iki şekilde kullanılmaktadır: Birincisi, ülkemizde her y1l artan dava sayısının esas nedeninin neler olduğu ve artan dava sayılarının hakim ve savcıların iş yükünü nasıl arttırdığıdır. İkincisi, iş yükünün artması sonucu hakim ve savc1 sayısının arttırılması sonucunun yarg1 bürokrasisi üzerindeki etkilerinin ne olduğuna ilişkindir. Ancak bürokrasinin olumsuzlukları üzerinden verimlilik değerlendirmesi yapmak bu alanda iș yükünün artmasının sadece bir sebebi olabilir.

İş yükünün azaltılması sorunu bürokratik yapılanmanın kat1, hiyerarşik yapısı yerine standart mahkeme sistemine alternatifler yaratarak rekabetin ve seçimin iyileştirilmesi yoluyla yarg1 verimliliğini arttıracağ1 yönündedir. Yargının iş yükünün azaltılması sürecinde alternatif uyuşmazlık yöntemleri ise dava sahiplerinin yavaş ve pahalı mahkeme süreçlerinden kaçınmalarını ve uyuşmazlıkların kısa sürede çözülmesi için firsat olarak düşünülmektedir (Botero, Porta, Silanes, Shleifer, Volokh, 2003: 252).

Bürokrasinin olumsuzlukları üzerinden yürütülen verimsizlik tartışması esasında daha fazla bürokratikleşmeye yol açmaktadır. Kapitalist sistemin işleyebilmesi, güvenilir ve hesaplanabilir ekonomik düzenlemeleri gerektirmesi ve ussal işleyişin sağlanmasında bürokrasinin varlığına gereksinim duyulmaktadır. Yargısal sorunların çözümünde sihirli değnek olarak görülen alternatif çözüm yollarının gereksiz yere dava açilmasina yol açan alanlar düzenlenmedikçe fayda sağlaması mümkün görünmemektedir. Tüketici mahkemelerinde görülen çok sayıdaki davanın bir kısmının hakem heyetlerine aktarılması sonuç olarak bu davaların varlığını ortadan kaldırmamaktadır (Sar1, 2016: 252).

\section{B. Adalet Hizmetlerinde Verimliliği Ölçme}

Kamusal hizmetlerin sayısallaştırılarak ölçülmesi, sonuçların başarı veya başarısızlık kriterleriyle belirlenmesi, sonucun kamuoyuna sunulmasi (Al, 2007: 5) düşüncesinin bir yansımasıdır. Toplumsal, kültürel ve ekonomik öğelerin de yer aldığı bu alanda yarg1 mekanizmasının düzgün işlemesinin önemli bir pay1 vardır. Her yıl devreden dosya sayılarının sistemin verimsizliği üzerine vurguları daha da arttırdığı bu durumu kanitlar niteliktedir. Adli yarg mahkemelerinde bir hakime düşen dosya sayısı 2011 yılında 1145 iken; 2018 yılında 806 olmuştur. Bu durumda, hakimlerin yıl içinde açılan dosyaları karara bağladıkları ancak önceki yıllardan devreden dosya sayılarının fazla olması sonucunda mahkemelerin iş yükünün azalmadığ 1 görülmektedir (Adli İstatistik, 2018). Hukuk mahkemeleri 2018 y1lı içinde dava türüne göre veraset davası açılan ve karara bağlanan dava türünün ilk sırasını oluşturmaktadır. Bu davalar hukuk mahkemelerinde açılan dava sayısının \%17.3'ünü oluşturmaktadır. İkinci sırada yer alan boşanma davası ise açılan davaların \%11.7'sini oluşturmaktadır (Adli İstatistik, 2018).

Yığılmış dosyaların bir sonraki senede eritilememesi geçen yıldan devreden dava sayıları, yıl içinde açılan dava sayıları ve bozularak gelen dosyaların varlığı sebebiyle işleyişte bir takım sorunlar ortaya çıkarmaktadır. Örneğin; ceza mahkemelerinde 2011 y1lında bir sonraki y1la devredilen dosya sayıs1 1.336.427 iken; bu say1 2018 y1lında 1.316.110 olmuştur. Yıl içinde açılan dava sayısı ise 2011'de 1.601 .859 iken bu say1 2018'de 1.601 .160 olmuştur. Ceza mahkemelerinin genelinde 2011 yllinda ortalama dava görülme süresi 266 gün iken; bu süre 2018'de 276 gün olmuştur (Adli İstatistik, 2018). Bunun yanında hakim ve savcı sayısını, yüksek mahkemelerin üye ve daire sayısını arttırmak, istinaf mahkemeleri kurmak ve alternatif uyuşmazlık yollarını geliştirmek yargıda mevcut işlevsel sorunların çözümü için yeterli olamamıştır (Çelik, 2015: 82). Ceza mahkemelerinde geçen y1ldan devren gelen dava sayıs 2011 'de 1.431.197 iken bu say1 2018'de 1.228.196 olmuştur. Yine ceza mahkemelerinin genelinde ortalama dava görülme süresi ise 2011'de 266 gün iken, 2018'de 276 gün olmuştur (Adli İstatistik, 2018). Bu durum ülkemizde yargısal işleyişin verimsizlik sorununun devamlılığına işaret etmektedir. 
Yargı sisteminde verimliliğin ölçülmesi, esasında sistemin işleyişiyle ilgili önemli ipuçları verebilir. Yargının verimliliğini ölçme konusu Avrupa Adaletin Etkinliği Komisyonu (CEPEJ) tarafından, Avrupa çapındaki mahkemelerin etkinliğini değerlendirmek üzere iki performans göstergesi geliştirilmesi yöntemiyle açıklanabilir. Birinci gösterge, bir devlette mahkemelerin gelen dava yüküyle ne kadar etkin biçimde başa çıktığını ölçen temizlenme oranıdır. İkinci gösterge ise, bir davayı sonuçlandırmak için tahmini olarak kaç gün gerektiğini ölçen dosya işlem süresidir (CEPEJ, 2016: 191).

\section{Kamuoyunda Verimlilik Algıs1}

Kamuoyunda yargının verimliliği çok çeşitli alt başlıklar göz önüne alınarak incelenebilir. Genellikle faklı çalışmalarda göze çarpan konu yargının bağımsızlığ1 konusunda somutlaşmaktadır. Ancak bağımsızlık düzgün işleyen bir yargı mekanizmasının ön koşuludur (Çelik, 2015: 77). Bu konuda yapılmış çalışmalar arasından özellikle seçtiğimiz "Adalet Gözet Projesi” kapsamında yapılan çalışmalar önemli bulgular içermektedir.

İstanbul Bilgi Üniversitesi İnsan Hakları Hukuku Uygulama ve Araştırma Merkezi tarafından yapılan "Adalet Gözet Projesi" yargı sisteminin işleyişine ilişkin vatandaşın özellikle odaklandığı sistemin eksiklikleri savıyla gerçekleştirilmiştir. Projenin önemli başlıkları, "davaların uzunluğu, artan iş yükünün ortaya çıkardığı sorunlar, hâkim ve savcı sayısının azlığı gibi konular yanında yargının işleyişindeki aksaklıkların tartış1lması ve değerlendirilmesi" açısından önemli veriler sunmaktadır ("İstanbul Bilgi Üniversitesi", 2006-2007).

Yine aynı projede yer alan bir başka çalışma olan Adalet Barometresi adlı çalışmada ise vatandaş ve hukuk arasında kopukluğun dikkat çektiğini ve bu kopukluğun giderilmesinde özellikle yargının vatandaşa sunduğu hizmetin erişilebilirliği ve kalitesini artırmaya yönelik geliştirilecek kapsamlı bir politikanın varlığ1 vurgulanmaktadır. Bu noktada özellikle mahkemelerin işleyişinde performans kriterlerinin belirlenmesinin öneminin alt1 çizilmektedir (Kalem, Jahic, Elveriş, 2008: 28).

\section{Alternatif Uyuşmazlık Yöntemlerinin Yargısal Verimliliği Arttırmada Etkileri: Tüketici Hakem Heyetleri}

Tüketici Hakem Heyeti, 6502 sayılı Tüketicinin Korunması Hakkında Kanun'un 66 ila 72. maddeleri arasında düzenlenmiştir. $\mathrm{Bu}$ düzenlemede "Başkanlığını illerde il Ticaret Müdürü, ilçelerde ise Kaymakam veya bunların görevlendireceği bir memur tarafından yürütülen" heyetin beş üyeden oluşacağ1 öngörülmüştür. Heyetin hukuki niteliği konusunda farklı görüşler olmasına rağmen bu konuda Anayasa Mahkemesi'nin vermiş olduğu karar önemlidir. Tüketici Hakem Heyetleri, mahkemelerin iş yükünü azaltmak adına oluşturulan alternatif uyuşmazlık yöntemlerinden birisidir. Anayasa Mahkemesi'nin ilgili kararı gereği (Anayasa Mahkemesi Kararı, 2014) hakem heyeti üyelerinin Anayasa'da belirtilen hâkimlik teminatlarına haiz olmadıkları ve uyuşmazlığın çözümü noktasında resmî olarak hâkim sıfatına haiz olmadıkları sebebiyle mahkeme niteliği taşımadığı belirtilmiştir (Ermenek, 2013: 575).

Buradan çıkartılabilecek sonuç, alternatif uyuşmazlık yöntemlerinin, yargı mekanizmasının yerine ikame edilmesi söz konusu olmayan, yargının iş yükünü büyük oranda azaltacak, uyuşmazlıkların çözümünü noktasında katk1 sağlayacak hukuksal korunma yöntemleri bütünü (Tanrıver, 2006: 154-155) olduğudur.

Yargının alternatifi olmayan, uyuşmazlıkların çözümünde yardımcı olabilecek bir mekanizma olarak nitelendirilen tüketici hakem heyetlerinin vermiş olduğu kararların bağlayıc1 olması, heyetin kararlarının niteliğinin tekrar düşünülmesini gerekli kılmaktadır. Tüketici mahkemelerinin iş yükünü azaltması ve tüketicilerin zararının giderilmesi adına oluşturulmuş bir müessese olduğu söylenebilir. Mahkeme olmadığ1 ileri sürülen heyete, belirli parasal miktarlara kadar başvurmanın zorunlu olduğu ${ }^{1}$ bilinmektedir. Belirlenen sinırlar altında kalan meblağların tüketici mahkemesi yerine heyete gitmesi mahkemenin yarg1 yetkisinin k1smen sinırlandırılıp; heyete bırakıldığı şeklinde düşünülebilir.

Tüketici mahkemelerine başvuru sayısı her y1 artarak devam etmektedir. 2011 y1lında toplam dava sayısı (geçen yıldan devreden, yıl içinde açılan ve bozularak gelen dosya sayıları) 43.588 iken; bu sayı 2018 'de 137.333 olmuştur. 2018 yllinda gelen davaların 2011 yılına göre \% 215'lik artış1 ise alternatif uyuşmazlık yollarının yargının iş yükü üzerinde nasıl bir etki yarattığ 1 üzerine önemli bir veridir ("Adli İstatistikler", 2018). Burada vurgulanması gereken nokta, alternatif uyuşmazlik yöntemlerinin işlevselliğinden çok yargısal talebin her sene neden arttığı olmalıdır. Bir mahkemenin bir yıl içinde önüne gelen dosya sayısını neden sonuçlandıramadığı sorusu önemlidir. Dava oranlarının yüksek olması elbette tek etkenle açıklanamaz. Adalet yönetiminin örgütlenme ve işleyişi yanında toplumsal ve kültürel etmenlerin de dava oranlarının artması ve iş yüküne yol açabildiğinin altı çizilmelidir.

Alternatif uyuşmazlık yöntemleri yargının iş yükünün azaltılmasına katkıda bulunacak usullerdir. Ancak yargının iş yükünün azaltılması ve yargıda verimliliğin sağlanması adına oluşturulan Tüketici Hakem Heyetleri'nin yeniden yapilandırılması gereği 1 Ağustos 2018 tarihi itibariyle sayılarının 1011'den

16502 Sayılı Tüketicinin Korunması Hakkında Kanunun 68 İnci Ve Tüketici Hakem Heyetleri Yönetmeliğinin 6.Maddelerinde Yer Alan Parasal Sinırların Artırılmasına İlişkin Tebliğ (1) 2020 y1lı için Tüketici Hakem Heyetlerine yapılacak başvurularda değeri:

a) 6.920 (altıbindokuzyüzyirmi) Türk Lirasının altında bulunan uyuşmazlıklarda İlçe Tüketici Hakem Heyetleri,

b) Büyükşehir statüsünde olan illerde 6.920 (altıbindokuzyüzyirmi) Türk Lirası ile 10.390 (onbinüçyüzdoksan) Türk Lirası arasındaki uyuşmazlıklarda İl Tüketici Hakem Heyetleri,

c) Büyükşehir statüsünde olmayan illerin merkezlerinde 10.390 (onbinüçyüzdoksan) Türk Lirasının altında bulunan uyuşmazlıklarda İl Tüketici Hakem Heyetleri,

ç) Büyükşehir statüsünde olmayan illere bağlı ilçelerde 6.920 (altıbindokuzyüzyirmi) Türk Lirası ile 10.390 (onbinüçüzdoksan) Türk Lirası arasındaki uyuşmazlıklarda İl Tüketici Hakem Heyetleri görevlidir. 
211 'e düşürüldüğü görülmektedir. Yargisal verimliliğin sağlanması adına oluşturulan yeni yöntemler Türk yarg1 sisteminin özellikleri düşünülerek değerlendirilmelidir. Makul sürede yargılama verimliliğin sağlanması açısından önemlidir. Ancak bu sorun verimlilik adına yargiya olan güveni azaltmamalıdır.

\section{SONUÇ}

Adalet yönetimi alanı, kamu yönetiminin bir çalışma alanı olarak araştırmacılara geniş bir çalışma imkânı sunmaktadır. Adalet yönetimi alanında var olduğu düşünülen gerek yapısal gerekse de işlevsel sorunların özüne inilerek kurumun güçlü ve zayıf yönleri ortaya konulmalıdır. Bu konuda geri bildirim mekanizmaları oluşturulmalı ve kamuoyu katılımı sağlanmalıdır. Son dönemde bu anlamda yapilan yargısal reformlar mevcut sorunların çözümünde önemli değişiklikleri beraberinde getirmiştir.

Verimlilik arayışları adına kamu yönetiminin varlik nedeni olan ilkeler elbette ki görmezden gelinmemeli, ancak bu kamu yönetiminin verimsizliğe ve hantallığa terk edilmesi anlamına da gelmemelidir (Ekşi, 2009: 498). Verimlilik kavramının disiplinin kendisini kurmasında ve tanımlamasında önemli bir yeri (Zengin, 2011: 46) olduğu unutulmamalıdır. Verimliliğin hem düşünsel, felsefi boyut içermesi, hem de bir analiz aracı olduğu ileri sürülebilir (Suiçmez, 2002: 169-170). Verimlilik olgusu sadece teknik açıdan ele alınmamalı ve Türkiye'nin toplumsal, tarihsel ve siyasal yapısı da göz önüne alınarak yeniden değerlendirilmelidir.

Yargının toplumsal boyutu göz önüne alındığında kamuoyunun yargiya olan güveni ciddi bir sorun alanıdır. Son dönem yapılan çalışmalar bu sorunun devam ettiği yönündedir. Verimlilik sorunu yargısal kararların niteliğini etkilememelidir. Dava yığılmasının sebepleri araştırılarak ortak bir konsensüsle çözüm arayışı sağlanmalıdır.

\section{KAYNAKÇA}

Adli İstatistikler (2017). Erişim Adresi: http://www.adlisicil.adalet.gov.tr/istatistik_2017 /istatistik2017.pdf

Adli İstatistikler (2018). Erişim Adresi. http://www.adlisicil.adalet.gov.tr/istatistik_2017 /istatistik2017.pdf

Aksoy, Ş. (2012). "Yeni sağ ve Devletin Değişimi" (2.Bas1). Burhan A. Şenol D. ve Hüseyin Y. (Ed.), Türkiye'de Kamu Yönetimi içinde. Ankara: Nobel Yayınlar1.

Al, H. (2007). "Kamu Mali Yönetimi ve Kontrol Kanunu ve Türk Kamu Yönetiminde Yeni Denetim Anlayışı" (1.Bas1). Bilal E. Musa E. ve Mustafa Lütfi Ş. (Edi.), Kamu Yönetimi Yazıları içinde. Ankara: Nobel Yayınları.

Anayasa Mahkemesi Kararı (2014, Ocak).Resmi Gazete (Say1: 2013/127 (Mükerrer)). Erişim adresi:http:/ / www.resmigazete.gov.tr/eskiler/201 4/12/20141212-15.pdf
Avrupa Birliği Müzakere Sürecinde Yarg1 ve Temel Haklar Fasl1, (2013). Ankara: MRK Bask1 ve Tanıtım Hizmetleri.

Avrupa Yarg1 Sistemleri Adaletin Etkinliği ve Kalitesi Avrupa Adaletin Etkinliği Komisyonu(CEPEJ) (2016). Duman Matbaas1.

Botero, J. C. Porta, R. L. López-de-Silanes, F. Shleifer A. ve Volokh A. (2003). The World Bank Research Observer, Vol. 18, No. 1.

Çelik, D. B. (2015). "Türkiye'de Yargının Verimliliği, Etkinliği ve Niteliği Üzerine Kimi Gözlemler". Finans Politik\&Ekonomik Yorumlar, C.52, S.610, 77-88.

Dava Şartı Arabuluculuk Uygulama Sonuçlarına İlişkin İstatistikler (2018).

http://www.adb.adalet.gov.tr/Sayfalar/istatistikle r/index.html

Diefenbach, T. (2018). "Why Michels' 'Iron Law of Oligarchy' Is Not An Iron Law - And How Democratic Organisations Can Stay 'OligarchyFree', Organization Studies ,1-18.

Doğan, A. ve Öztürk, A. (2018). “Türkiye'de Adalet Hizmeti Harcamaları". Süleyman Demirel Üniversitesi İ̈BF Dergisi, C.23, 778-779.

Egeli, H. ve Yaşa, A. A. (2017). "Devlet Bütçesi açısından Adalet Hizmetleri ve Harcamaları: Türkiye Üzerine Bir Değerlendirme". Eskişehir Osmangazi Üniversitesi İ̈BF Dergisi, C.12, S.2, 8394.

Ekşi, H. (2009). "Kamu Yönetiminde Değişim ve Yeni Yönetim Modelleri”. Sosyal ve Ekonomik Araştırmalar Dergisi, C.9, S.17, 491-500.

Ergun, T. (2012). "Kamu Yönetimi Disiplininde İnceleme Nesnesi Sorunu" (2.Bas1). Burhan A. Şenol D. Hüseyin Y. (Ed.) Türkiye'de Kamu Yönetimi içinde, Ankara: Nobel Yayınları.

Ermenek, İ. (2013). “ Yarg1 Kararları Issı̆̆ında Tüketici Sorunları Hakem Heyetleri Ve Bu Alanda Ortaya Çıkan Sorunlara İlişkin Çözüm Önerileri”. Gazi Üniversitesi Hukuk Fakültesi Dergisi, C. XVII, Y.2013, 563-630.

Eroğul, C. (2014). Devlet Nedir?. İstanbul: Yordam Kitap.

Ery1lmaz, B. (2013). Kamu Yönetimi-DüşüncelerYapılar-Fonksiyonlar-Politikalar (6.Bas1). Kocaeli: Umuttepe Yayınlar1.

Gülener, S. (2011). "Yarg1 Bağımsızlığını Güçlendirici bir Mekanizma Olarak Yargisal Hesap Verebilirlik ve Türk Yarg1 Sistemi”. Gazi Üniversitesi Hukuk Fakültesi Dergisi, C.XV, 215-252.

Güler, B. A. (2012). "Nesnesini Arayan Disiplin: Kamu Yönetimi". B. Aykaç, Ş. Durgun ve H. Yayman, (Ed.), Türkiye'de Kamu Yönetimi İçinde. Ankara: Nobel Yayıncilik. 
Güler, B. A. (2013). Türkiye'nin Yönetimi-Yap1(4.Bas1). Ankara: İmge Yayınlar1.

Güler, B. A. (2016).Yeni Sağ ve Devletin DeğişimiYap1sal Uyarlama Politikaları 1980-1995 (3.Bas1). Ankara: İmge Yayınları.

İhtiyari Arabuluculuk Uygulama Sonuçlarına İlişkin İstatistikler (2018). Erişim adresi: http://www.adb.adalet.gov.tr/Sayfalar/istatistikle r/index.html

İstanbul Bilgi Üniversitesi (2006-2007). Erişim Adresi: https://insanhaklarimerkezi.bilgi.edu.tr/tr/publi cation/23-adalet-gozet-yarg-sistemi-uzerine-birinceleme

Kalem, S. Jahic, G. ve Elveriş İ. (2008). Adalet Barometresi; Vatandaşlarin Mahkemeler Hakkındaki Görüşleri ve Değerlendirmeleri (1.Bas1). İstanbul: İstanbul Bilgi Üniversitesi Yayınlar1.

Kilim, E. E. (2013). Türkiye'de Adalet Yönetimi, Bağımsız Yargının Sıkı Bağları. Ankara: Siyasal Kitabevi.

Konca, N. K. (2018). Ticari Uyuşmazlıklarda dava şartı Arabuluculuk. Erişim adresi: https://setav.org/assets/uploads/2019/01/225. pdf

Mihçıŏlu, C. (2012). "Kamu Yönetiminde Reform”. B. Aykaç, Ş. Durgun ve H. Yayman, (Ed.), Türkiye'de Kamu Yönetimi İçinde, (Ankara: Nobel Yayınları.

Mihçıŏlu, C. (2003). "Kamu Yönetiminde Verimlilik". B. Aykaç, Ş. Durgun ve H. Yayman, (Ed.), Türkiye'de Kamu Yönetimi İçinde. Ankara: Yarg1 Yayınları.

Peters, B. G. ve Pierre, J. (1998). "Governance without Government? Rethinking Public Administration". Journal of Public Administration Research and Theory: J-PART, Vol. 8, No. 2, 223-243.

Sarı, C. (2016). "Türkiye'de Yargının Sorunları Ve Çözüm Yolu: Weberyanist Yargıdan Yalın Yargıya". $T A A D, \mathrm{Y}: 7, \mathrm{~S}: 26,257-259$.

Sever, Ç. (2016). "Adalet Hizmetlerinden Doğan Mali Sorumluluk". Ankara Barosu Dergisi, 2016/1, 4380.

Suiçmez, H. (2002). "Verimlilik ve Etkinlik Terimleri(Tarihsel Bakış)”. Mülkiye, C.XXVI, S.234,169-183.

Tanrıver, S. (2006). "Hukuk Uyuşmazlıkları Bağlamında Alternatif Uyuşmazlık Çözüm Yolları Ve Özellikle Arabuluculuk". TBB Dergisi, S. 64, 151-177.

Teziç, E. (2013). Anayasa Hukuku (16.Bas1). İstanbul: Beta Yayınc1lik.
Tüketicinin Korunması Hakkında Kanunun 68 İnci Ve Tüketici Hakem Heyetleri Yönetmeliğinin 6.Maddelerinde Yer Alan Parasal Sinırların Artırılmasına İlişkin Tebliğ (2019). Erişim adresi: http://tuketici.gtb.gov.tr/data/5a4e129eddee7d1 fa8b6bfaa/teblig.pdf

Övgün, B. (2010). Devlet ve Planlama. Ankara: Siyasal Kitabevi.

Övgün, B. (2013). Türkiye'de Kamu Yönetiminin Dönüşümü. Ankara: Nika Yayınevi.

Özer, M. A. (2013). "Weber'in Bürokrasisi Karşısında Yönetimde Yeniden Yapılandırma Arayışları". Küresel İktisat ve İşletme Çalışmalar Dergisi, C.2, S.4, 43-57.

Waldo, D. (1948). The Administrative State: A Study of the Political Theory of American Public Administration, New York: The Ronald Press Company.

Waldo, D. (1968). "Public Administration". The Journal of Politics, Vol. 30, No. 2, 443-479.

Weber, M. (2005). Bürokrasi ve Otorite, H. Bahadır A. (Çev.), Ankara: Adres Yayınları.

Yarg1 Reformlarına İlişkin AB-Türkiye İşbirliği (2019). Erişim adresi: https://www.avrupa.info.tr/tr/yargireformlarina-iliskin-ab-turkiye-isbirligi-39

Yargıtay, İş Süreçlerinin Yeniden Yapılandırılması ve Verimlilik Kontrolü Projesi Bilgi Notu (2018). Erişim adresi: https://www.yargitay.gov.tr/icerik/1213

Zengin, O. (2011). “Amerikan Kamu Yönetimi Disiplininin Kuruluşunda Verimlilik Olgusunun Yeri”. Mülkiye, C. XXXV, S.273, 43-54. 